\title{
Agricultural history nexus food security and policy framework in Tanzania
}

\author{
Msafiri Yusuph Mkonda ${ }^{1 *}$ and Xinhua $\mathrm{He}^{2,3}$
}

\begin{abstract}
Background: Understanding the production trend of the major food crops is an important step for any nation that evaluates her agricultural progress. This evaluation should mostly focus on the yields per unit area. So far, it can also earmark the expansion of farms to determine the general yields trend. The main objective of this paper is to assess the production trend of the major food crops and their efficacy to food security in Tanzania. This is particular important because for the past three decades, the country has failed to control food security (especially food availability and accessibility).

Results: Here, crop data from 1980 to 2015 were gathered from the Ministry of Agriculture, Livestock and Fishery (MALF), and in the respective regions. In some incidences, the regional data were averaged to elicit their preciseness. To determine the objectivity of this study, agricultural policy, programs, and plans from MALF were reviewed for similar purpose. Mostly, the Mann-Kendal Test and Microsoft Excel were used for data analyses. The results show that the production of the total yields had a positive trend (i.e., growing at $R^{2}=0.4$ and 0.8 ), while that of the yields (ton/ha) had a negative trend (i.e., declining at $R^{2}=0.02$ and 0.3 ). It was further realized that the total yields mostly boomed due to farm expansion.

Conclusions: Despite the efforts from various agricultural stakeholders, the country has not yet achieved a sustainable crop yield and food security. Explicitly, this situation has been affecting peoples'livelihoods, and other sectors either directly or indirectly. Therefore, there is a need to improve the production strategies and approaches (i.e., more especially technology and marketing) to limit this problem.
\end{abstract}

Keywords: Agricultural production trend, Crop yields, Food security, Policy, Programs, Tanzania

\section{Background}

Since the inception of Tanzania in 1964, the country's population has increased to about five times, from approximately 11.7 million in 1965 to more than 53.4 million in 2015 [1-3]. The demand placed on national agricultural production arising out of population and economic growth has enormously increased [4-7]. Despite the increase in both land expansion and agricultural development, the problem of food security has remained unresolved $[8,9]$. Reports from both domestic and international agencies such as FAO have reinstated

\footnotetext{
*Correspondence: msamkonda81@yahoo.co.uk

1 Department of Geography and Environmental Studies, Solomon Mahlangu College of Sciences and Education, Sokoine University of Agriculture, Morogoro 3038, Tanzania

Full list of author information is available at the end of the article
}

the same. In Tanzania, the agricultural sector has a substantially outstanding contribution to socioeconomic development as it supports the GDP (Gross Domestic Product) with $28 \%$, provides $95 \%$ of the food and employs over $75 \%$ of the national labor forces [3].

In that respect, agricultural growth has a direct contribution to food security and economic growth of the country and livelihoods of the people. However, some regions have favorable biophysical characteristics (i.e., soils, water sources and climate just to mention a few) than others. Potentially, this differential biophysical endowment has significant implications to crop yields. Ultimately, this situation leads to differential agricultural outputs among the regions within the country $[9,10]$.

Generally, the country has a wide range of agricultural potentials such as 44 million hectares of arable land, numerous rivers for irrigation, labor force, policies and 
programs just to mention a few. Nevertheless, less than $24 \%$ and $4 \%$ of the arable land and irrigation potentials has been harnessed, respectively. This inefficient utilization of resources has been attributed by low investment in the sector in terms of finance and technology and ultimately resulted to low productivity. Preferably, maize is a staple food to about $70 \%$ of the Tanzanians, while sorghum, millet, paddy, banana, cassava, wheat and diverse varieties of potato just to mention a few are dominant food crops depending on the regional preferences.

Although the assessment of crop production and associated challenges is progressing rapidly, a variety of knowledge gaps still exist. Despite the implementation of programs and initiatives, yet there is high inconsistence of crop yields that always lead to enormous food shortage and insecurity in Tanzania [2, 3, 10, 11]. This study aims to assess the efficacy of the major food crop production and its implications to food security, economic development and policy framework. It intends to depict the balance between the efforts placed in the production process and its return. By determining such a balance, this study will be capable to propose strategies at local and policy level that would optimize yields to sustain the livelihoods of over $80 \%$ smallholder farmers who entirely depend on rain-fed agriculture.

To meet the study objective, this paper attempts to answer the following questions: (1) How did the production trends of the major food crops behave in the past three decades? (2) Were the obtained yields enough for food requirement? (3) What were the main factors that influenced the production trend? (4) How policy framework and other associated programs influenced the efforts for yield optimizations? (5) What should be done to intensify crop production with higher yields that can ensure food security and economic development?

\section{Methods}

\section{Profile of the study site}

Tanzania is located on the eastern coast of Africa, south of the Equator between latitudes $1^{\circ} 00^{\prime} \mathrm{S}$ and $11^{\circ} 48^{\prime} \mathrm{S}$ and longitudes $29^{\circ} 30^{\prime} \mathrm{E}$ and $39^{\circ} 45^{\prime}$. Eight countries: Kenya and Uganda in the north, Rwanda, Burundi, Democratic Republic of Congo and Zambia in the west, Malawi and the Republic of Mozambique to the south share boundaries with Tanzania. The eastern side of Tanzania is a coastline of about $800 \mathrm{~km}$ long marking the western side of the Indian Ocean. Tanzania has a total of $945087 \mathrm{~km}^{2}$, and out of this area, water bodies cover $61,495 \mathrm{~km}^{2}$ which is equivalent to $6.52 \%$ of the total area.

The mean annual rainfall varies considerably from place to place ranging from less than $400 \mathrm{~mm}$ to over $2500 \mathrm{~mm}$ per annum. Rainfall in about $75 \%$ of the country is erratic, and only $21 \%$ of the country can expect an annual rainfall of more than $750 \mathrm{~mm}$ with a $90 \%$ probability. Intergovernmental Panel on Climate Change (IPCC) [12] informed that Tanzania and other sub-Saharan African countries will continue to be vulnerable to the impacts of climate change (i.e., excessive droughts). This is caused by their weak adaptive capacities. The current report by IPCC [13] slotted Tanzania as among the thirteen countries that area worst affected by the impacts of climate change and vulnerability and has weak adaptive capacities to cope or recover from the stress. The report further described that if proper adaptation measures are not virtually taken, more significant impacts will stress the country.

Since soil is the major determinant of agricultural production as it acts as a mother factor for the whole process, it was liable to understand the dominant types of the soil in the country. According to World Reference Base of Soil Resource (WRB), Tanzania has 19 dominant soil types and they are grouped into two groups, namely organic soil and mineral soils. The structure, concepts and definitions of the WRB are strongly influenced by (the philosophy behind and experience gained with) the FAO-UNESCO Soil Classification System [14, 15]. Literally, Tanzania has different types of soils such as clay, loam and sand as identified by the normal farmers. These soil types have different potentials in terms of fertility and moisture conservation for crop production.

Ecologically, the Rufiji, Ruvu, Wami, Ruaha, Kilombero, Malagarasi and Pangani basins form numerous hydro-ecological zones in Tanzania that provide fruitful potentials for crop production. Similarly, the existence of diverse agro-ecological zones in the country has significant potentials to sustainable crop production. These biophysical potentials including the 44 million hectares of arable land are convenient for the progression of agricultural industry in the country [3].

\section{Data collection and analyses}

This study was designed to typically entail the long-term (1980-2015) crop data from authentic sources. The yield data for major food crops were collected from March to December 2016 at the Ministry of Agriculture, Livestock and Fishery (MALF), and at regional and district levels. The data were particularly gathered from documentaries (statistic unit) of the ministry. Interviews with some agriculture officials at the ministry were employed to collect qualitative data and cross-check some quantitative data.

In some instances, it happened that some years had no data. Other data were collected from ten (10) regions earmarking the regions which are best and least producers of food crops. Among these regions are Iringa, Mbeya, Kigoma, Tabora, Kilimanjaro, Kagera, Lindi, Ruvuma, Singida and Dodoma. Then, the data from these areas 
were cross-checked with those documented at MALF. Then, the mean was calculated to harmonize some raised discrepancies and missing data.

To correct this, we searched the missing data at regional and district level to obtain the same. Where necessary, we estimated the data below $5 \%$ to avoid erroneous. National Agricultural Policy of 2013 and its allied programs from the Ministry were equally consulted during data collection. Since most of data were quantitative in nature, we employed the Mann-Kendall Test and Microsoft Excel to plot the yield trends. Qualitative data especially those from interviews were analyzed through content method, and the results were inserted in the main text during discussion.

\section{Results}

\section{Trends of crop production}

This empirical study has succeeded to perform the temporal analyses for yields of the major crops. The results show that the yields have had high inconsistence throughout the time frame (1980-2015). This is evident in Figs. 1a, b, 2a-c, 3a-c and $4 \mathrm{a}-\mathrm{c}$ where the yields of maize, paddy, millet, sorghum, cassava, banana, potatoes and wheat have been plotted against time and thus far, have shown unreliability. This plotting entailed two major dimensions that would determine the quantity of yields. Firstly, it involved the total yields in tons and secondly was about the yields per hectare in tons. On the basis of total yields, the production trend for maize, banana, beans and sorghum exhibited a positive slope (significant growth at $R^{2}=0.8$ ), as well, that of paddy, cassava, millet, wheat and potatoes showed a positive slope (between $R^{2}=0.4$ and 0.7), as seen in Fig. 1a, b. Besides, the yields per hectare in tons exhibited a negative slope (between $R^{2}=0.02$ and 0.3 ) as seen in Figs. 2a-c, 3a-c and $4 \mathrm{a}-\mathrm{c}$. These results depict the widest context of crop yields at national level.

Further, the present study has revealed that there has been a temporal expansion of crop land as presented in Table 1. Explicitly, this has been a major cause for the total yield to boom. For example, within a period of two decades the crop land under maize increased for about three times, while that of sorghum, millet and cassava have more than doubled. While the land under crop production has experienced significant increase from 1996 to 2015 , the population has almost doubled within such a time frame and thus, increasing more food demand.

\section{Implications to food security}

The results from analyses have a message to convey to agricultural and social livelihood analysts. This is about the implications of what has been gotten from farms (yields) and the particular food requirements at household and national level. According to FAO, food security encompasses three major aspects, namely availability, accessibility and use. In the Tanzanian context, all the three aspects are dominant. Along these aspects, poverty (entitlement failure) has also exacerbated the magnitude of food insecurity. Since more than $90 \%$ of the food requirement is produced in the country; thus, whatsoever come from the farm determines the food security status. Overall, the production turbulence as seen in Figs. 1, 2, 3 and 4 indicates the unsustainability of food security in the country.

There has been a correlation between the amount of obtained yields and the level of food security; as regions with low self-sufficient ratio have been experiencing intensive food shortage. For example, most regions found in arid and semiarid zones have been suffering from all three aspects of food security. The food produced has always been outsmarted by the requirements; thus, food availability is not ensured. On the other hand, people (i.e., especially the destitute) have weak purchasing capacity to access food in market and ultimately, bringing about food shortage and insecurity. These results are in agreement with the government report as recently in $2013 / 2014$, there was a food deficit of 43,452 tons [11]. That deficit happened because the total food requirement was $7,656,673$ tons, but the production was placed at $7,613,221$ tons.

\section{Hindrances for crop production}

There have been numerous challenges contributing to agricultural unsustainability in the country. These challenges range from natural to human-induced problems. Reports from IPCC, FAO and other international organizations have revealed that climate change has posed severe impacts to agricultural sector in most developing countries $[6,12,13]$. In this era of global climate change, the poor nations like Tanzania are most vulnerable and are weak to cope or recover from such dreadful condition. Besides, the study by URT (United Republic of Tanzania) [2, 3, 10], Kangalawe [16], Rowhani et al. [17], Neufeldt et al. [18] and Paavola [19] further asserted that climate change has already affected and will continue affecting poor households in most developing countries and thus, increasing the vulnerability of the dependable livelihoods.

In some ways, the government has contributed to such unsustainability due to low investment in the sector. It is understandable that for the sector to progress, at least $10 \%$ of the developmental budget should be placed in it.

However, good step has left unimplemented despite establishing some initiatives to overcome the crisis. At farmer's level, Tanzanian agriculture is predominated by small-scale holders for over $70 \%$. This dominance is 

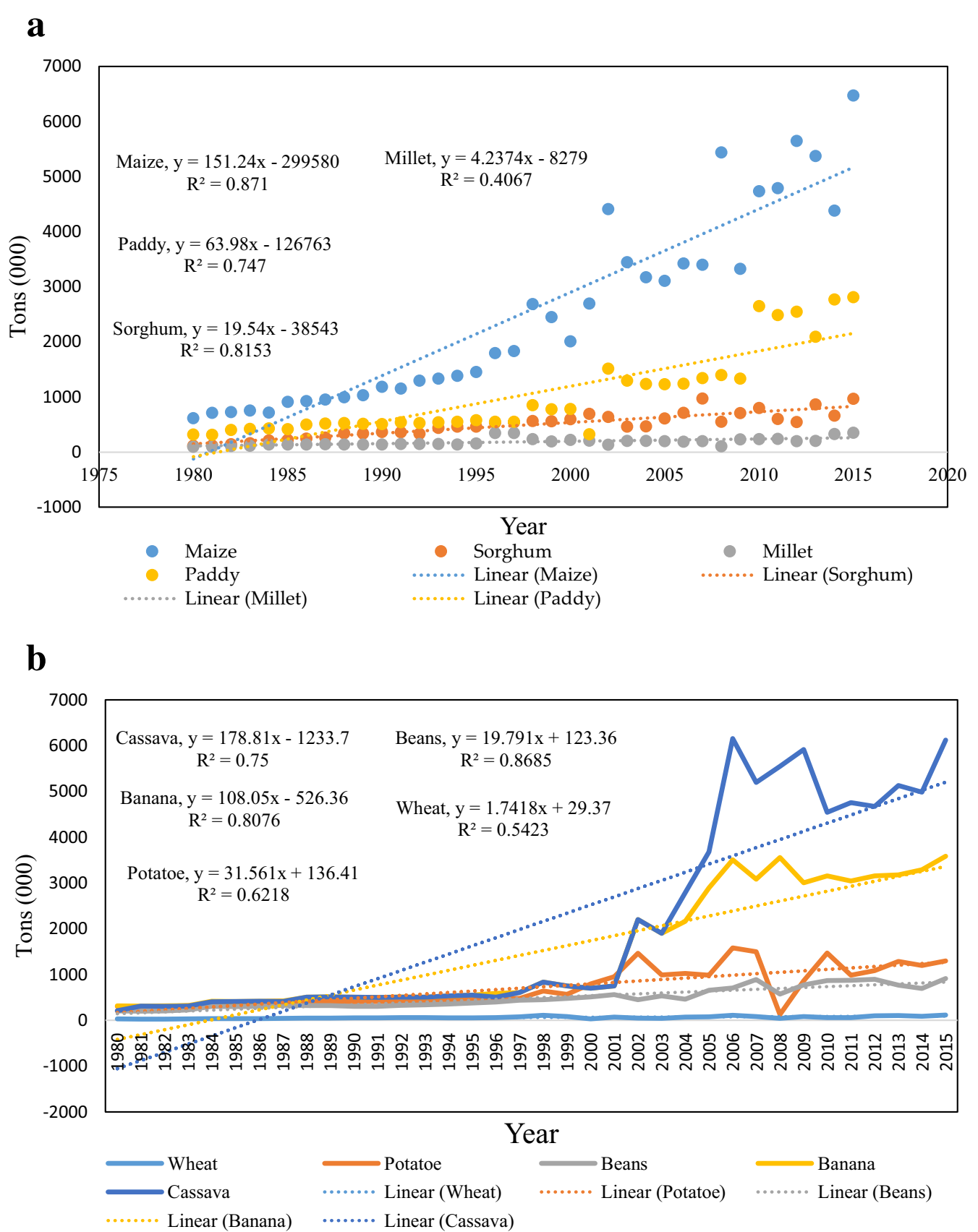

Fig. 1 Yields trend of the major food crops in Tanzania from 1980 to 2015. a Yields trend for maize, sorghum, millet and paddy, b yields trend for wheat, potatoes, beans, banana and cassava Source: Analyses from the data obtained from MALF

even higher in rural areas where it exceeds $80 \%$. Unfortunately, this farming scale is meant for subsistence and not for commercial purpose. However, despite targeting for subsistence, these farmers have in most cases failed to meet their minimum requirement due to meager yields obtained from their farms. Correspondingly, it is this vulnerability that has contributed to decline in yields per hectare in tons as seen in Figs. $2 \mathrm{a}-\mathrm{c}, 3 \mathrm{a}-\mathrm{c}$ and $4 a-c)$. Besides, the market constraints and increased poverty among the rural households are some of the salient factors for agricultural dwindling [3]. Overall, the human-induced factors have been increasing over time because the rate of solving them is surpassed by that of its creation. 

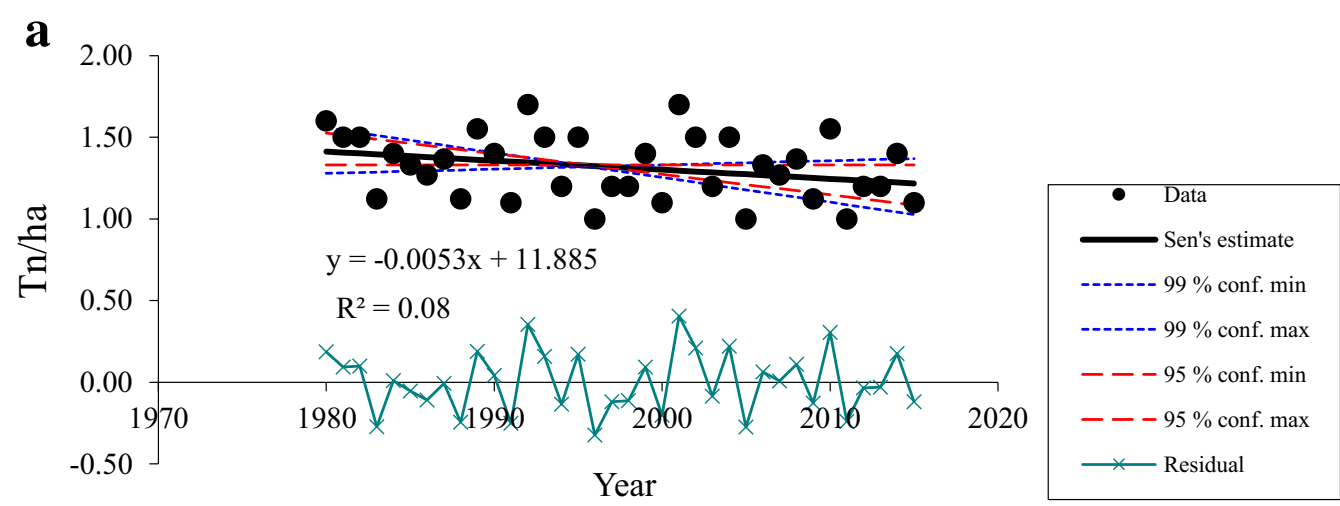

b
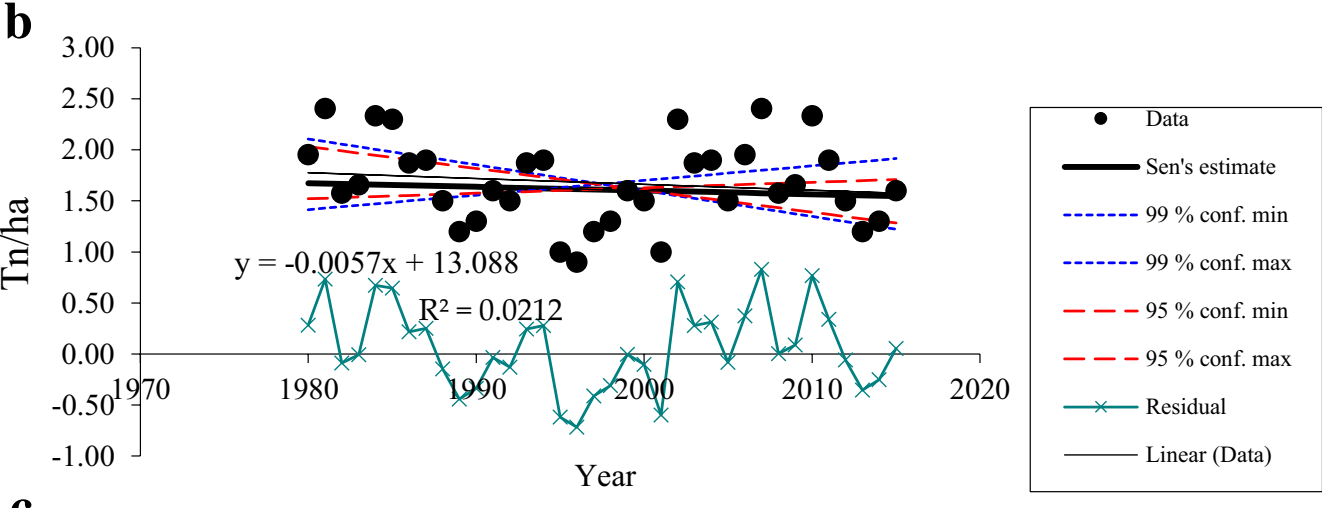

c

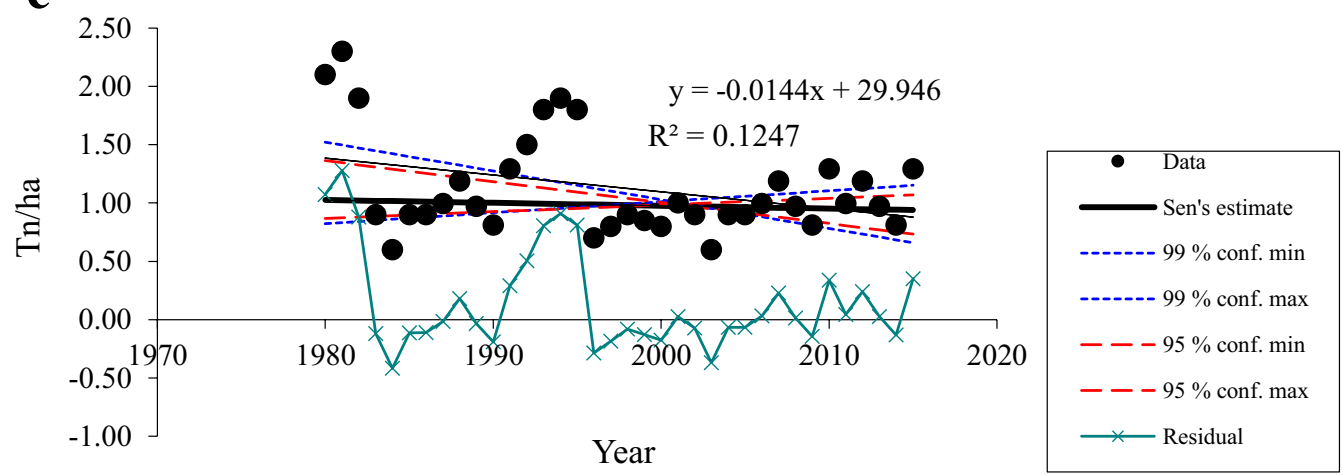

Fig. 2 Yields of the major food crops per hectare in tons in Tanzania from 1980 to 2015. a Maize yields per hectare in tons, b paddy yields per hectare in tons, c sorghum yields per hectare in tons Source: Analyses from the data obtained from MALF

\section{Policy framework entailed in crop optimizations}

National Agricultural Policy (NAP) [3] is the main document responsible for agricultural sector in Tanzania. The main aim of this policy is to optimize crop production for food security and economic development. Its implementation is done in a series of programs, initiatives, strategies, plans and projects. Among these, the Agricultural Sector Development Program (ASDP) was launched in 2005 to implement the Agricultural Sector Development Strategy (ASDS) of 20013.

In addition, PADEP-Participatory Agricultural Development and Empowerment Project (2003),
TAFSIP-Tanzania Agriculture and Food Security Investment Plan (2011-2021) and Agricultural First (locally, Kilimo Kwanza) Initiative of 2009 were equally introduced to spearhead agricultural production. Externally, the Comprehensive Africa Agricultural Development Program (CAADP) is an initiative to improve food security in most African countries in which Tanzania is inclusive. Altogether, these programs and initiatives meant to raise agricultural produce, especially for rural households in order to optimize crop production. However, despite these programs and initiatives, little has been achieved. 

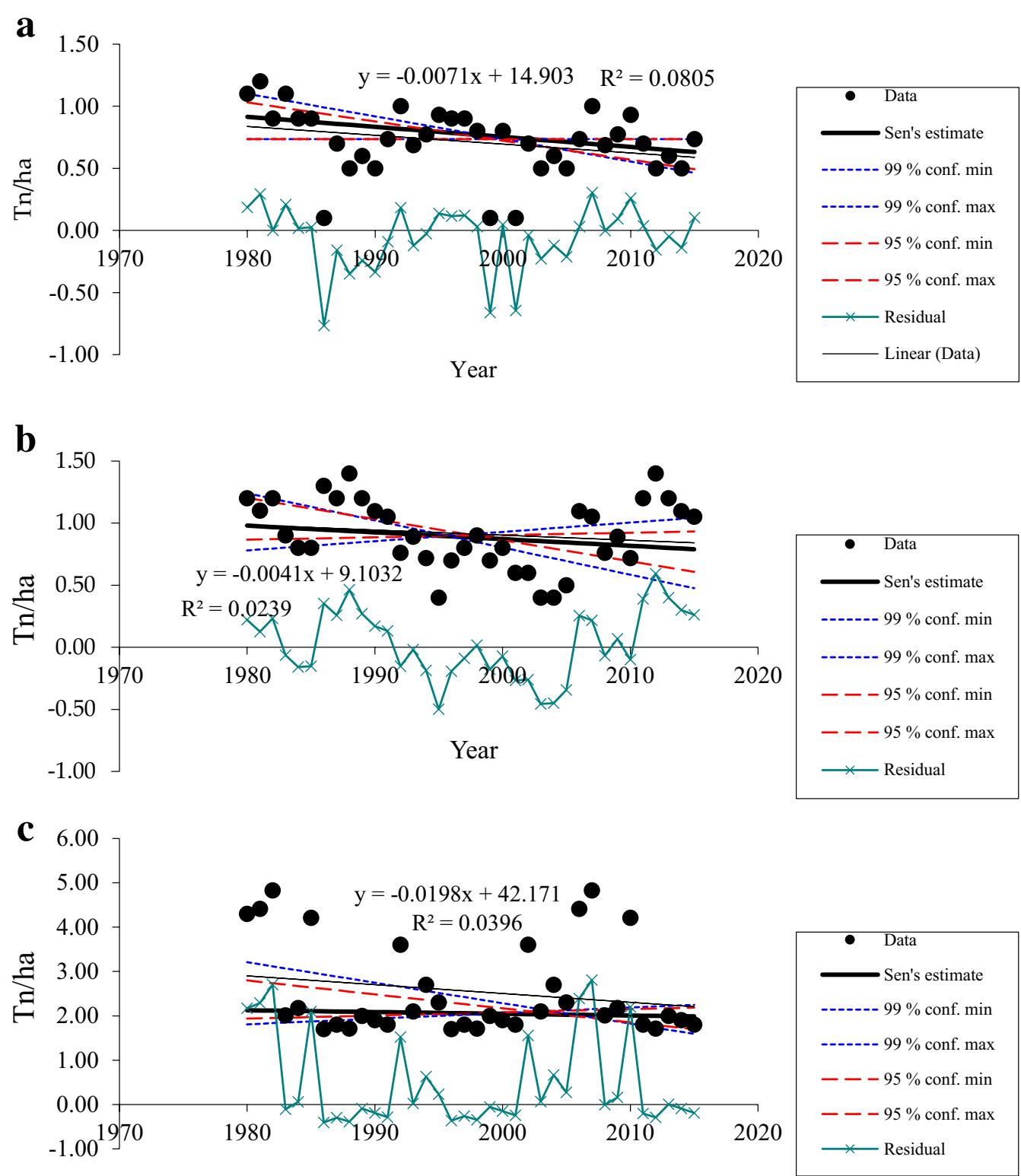

Fig. 3 Yields of the major food crops per hectare in tons in Tanzania from 1980 to 2015. a Millet yields per hectare in tons, $\mathbf{b}$ beans yields per hectare in tons, $\mathbf{c}$ potatoes yields per hectare in tons Source: Analyses from the data obtained from MALF

\section{Discussion}

The results of this empirical study can be among the best platforms to discuss where and why we do not do much better as a nation. This is because for the past three decades (study time coverage), lots have been reported as food shortage. More unfortunately, this crisis has been almost randomly scattered throughout the country although the semiarid areas have been more susceptible. As confirmed in Figs. $1 \mathrm{a}, \mathrm{b}, 2 \mathrm{a}-\mathrm{c}, 3 \mathrm{a}-\mathrm{c}$ and $4 \mathrm{a}-\mathrm{c}$, and Table 1, Tanzanian agriculture is inconsistent, and thus, as a nation, has still a long way heading to productive and sustainable industry. While the production trend of total yields for maize, sorghum, banana and beans had a positive slope (at $R^{2}=0.8$ ), the remaining crop yields had a positive slope (between $R^{2}=0.4$ and 0.7 ) as seen in Fig. 1a, b.

However, this growth was highly influenced by expansion of crop land (Table 1). For example, the areas under maize, sorghum, paddy, millet and cassava cultivation have increased from 1,343,300, 566,700, 434,500, 243,200 and 265,500 in 1996 to $3,854,600,1,389,600,1,364,300$, 467,900 and $1,254,300$ in 2015 , respectively (Table 1 ). 

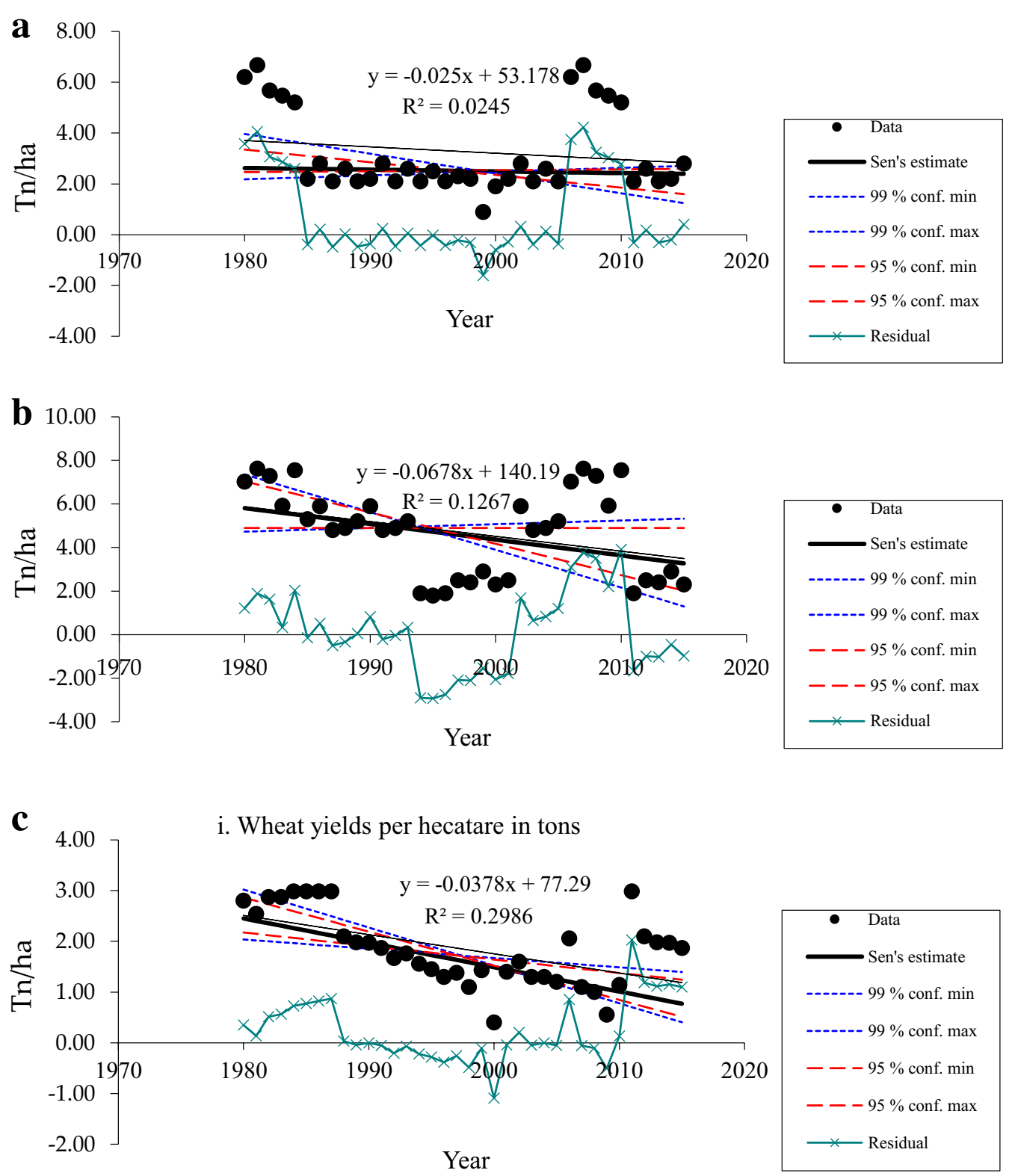

Fig. 4 Yields of the major food crops per hectare in tons in Tanzania from 1980 to 2015. a Cassava yields per hectare in tons, b banana yields per hectare in tons, $\mathbf{c}$ wheat yields per hectare in tons Source: Analyses from the data obtained from MALF

Despite this, the country has not yet fully harnessed the potential arable land as less than $24 \%$ of the 44 million hectares of parable land has been under effective utilization 3. This, therefore, indicates that we have still lots to do if need to attain sustainable crop yields and food security at both local and national level.

In due fact, this farm expansion has on one side been accrued by population increase. In other words, there has been insignificant increase in the yields even in regions called the food-producing zones or food basket regions
$[2,3]$. Frankly speaking, different regions have been experiencing different crop yields. This spatial differentiation is mainly influenced by diverse biophysical characteristics of the locality, i.e., climate, soil and agro-ecological zones just to mention a few. However, the gotten yields (i.e., increased) have not curbed the food demand, especially at national level [20], and more particularly on the food availability and accessibility. For that case, the food demands have continued to widen over time. Thus, in most cases the growth of the total yields has 
Table 1 Area under crop production in ' 000 ' hectares by region Source: Extracted from MALF, 2016

\begin{tabular}{cccccc}
\hline Year & Maize & Sorghum & Millet & Paddy & Cassava \\
\hline 1996 & 1343.3 & 566.7 & 243.2 & 434.5 & 565.5 \\
1997 & 1564.1 & 874.2 & 253.6 & 439.3 & 559.4 \\
1998 & 2088.3 & 618.4 & 268.1 & 654.5 & 599.4 \\
1999 & 1764.4 & 685.5 & 295.8 & 473.9 & 779.3 \\
2000 & 1870.5 & 817.9 & 251.8 & 517 & 1824.5 \\
2001 & 1572.2 & 566.7 & 201.1 & 323.7 & 905.5 \\
2002 & 2956.7 & 874.2 & 227.3 & 642.7 & 752.7 \\
2003 & 2852.3 & 618.4 & 225.2 & 688.5 & 1191.9 \\
2004 & 2854.2 & 715.8 & 225.8 & 689.6 & 1313.1 \\
2005 & 2854.5 & 817.9 & 227.9 & 691.2 & 1345.4 \\
2006 & 2570.9 & 715.8 & 338.6 & 633.7 & 993.2 \\
2007 & 2600.3 & 817.9 & 346.8 & 557.9 & 779.1 \\
2008 & 3980.9 & 1239.3 & 355.7 & 887.7 & 876.9 \\
2009 & 2961.3 & 1323.4 & 396.5 & 805.6 & 1081.4 \\
2010 & 3050.7 & 1239.3 & 452.7 & 1136.3 & 872.9 \\
2011 & 3056.7 & 1323.4 & 456.5 & 1143.3 & 890.5 \\
2012 & 3058.8 & 1148.3 & 457.6 & 1174.5 & 954.4 \\
2013 & 3730.5 & 1170.8 & 421.2 & 1276.4 & 1034.5 \\
2014 & 3729.5 & 1285.7 & 453.2 & 1254.7 & 1154.8 \\
2015 & 3854.6 & 1389.6 & 467.9 & 1364.3 & 1254.3 \\
\hline
\end{tabular}

not necessarily implied agricultural development. This is because there are other aspects that determine such development apart from the total yields.

The exploration of crop yields per hectare in tons is far most the best way of determining the actual agricultural development. The analyses in this aspect had a real basis of determining agricultural progress. This is because it can supply more food to sustain the rapidly growing population. However, the results from analyses of yields per hectare in tons indicate that almost each crop experienced negative growth as seen in Figs. 2a-c, $3 \mathrm{a}-\mathrm{c}$ and $4 \mathrm{a}-\mathrm{c}$. From 1980 to 2015, the yields for these crops declined between $R^{2}=0.02$ to 0.3 (Figs. 2a-c, 3a-c and $4 \mathrm{a}-\mathrm{c})$. This means, the production trend per hectare has been deteriorating over time due to multiple reasons such as soil degradation, increased droughts, poor farming methods, eruption of diseases and less investment in agricultural sector, especially research. Apparently, the increased incidences of climate change impacts have contributed to worsen the situation $[13,17]$.

Apart from establishing the correlation between the components under study, the present study elicits or/and annotates specific aspects that categorizes the country as food insecure [21-23]. The production systems seem to be less monitored as anyone can join or quit agricultural production. This reminds us that there is a possibility of the majority abandoning the sector or opting transformative adaptation due to climate change. Thus, all the suddenly, the situation can be at its worst and little can be done by the government and/or donors to rescue the victims in such massive mess.

In addition to that, despite employing over $80 \%$ of the labor forces, especially in rural areas, the sector has failed to attract more young generation because it is perceived as the least paying. This has been evidenced in various occasions where the farmer has remained with very little control on marketing his/her yields. For example, the government may come abruptly to solve immediate problem at the expenses of the farmer who had anticipated to sell their yields in the market of their favor.

For example, exporting maize or selling in its raw form to get more income. The discussion with undisclosed agricultural officers had some blames being directed to some politicians who always don't adhere to the technical aspects. Most of this people from political cadre do this reckless tendency deliberately to win political credit.

Given the production turbulent which the country experiences, it is evident that the efforts that have been placed in the sector have not born enough fruits. The episode of making agriculture as a backbone of the national economy that started (back in 1970s) over four decades ago using different approaches has never been fruitful. For example, in 1980s the government involved directly in agriculture by making herself a funder, facilitator and supplier of agricultural inputs that would boost its development; however, this approach was fruitless. One of the major reasons for this failure was weak supervision of the government firms, infrastructures and assets. Ultimately, government companies and factories ran into bankrupt and the approach ended unsuccessfully.

Recently (2000s), numerous participatory approaches have been adopted in the planning and implementation of various agricultural practices as a substitute of the previous approach. The PADEP, ASPS, ASDP and Kilimo Kwanza are among these programs and initiatives that were geared to boost agriculture industry in the country 11, 29. The NAP 2013 serves to give guidance on how agriculture sector should go about. Mainly it implies to optimize yields from agriculture for the betterment of people's social welfare. Originally, this policy was enacted in 1997, whereas amendment and new draft was in 2013. However, despite giving explicit concept on the available resources for sustainable agricultural development, there are some agricultural aspects that are not well addressed. Most of these are the new challenges that emanates/ comes as response from human-induced factors.

As a response to agricultural uncertainty, the NAP 2013 [3] has been emphasizing on the adaptation measures to climate change impacts, intensification of agriculture and the use of improved crop seeds among the farmers. 
However, despite those responses the state of food security has not been stabilized as in the series of years from 2000 to 2014; there have been frequent food shortages in various area of the country (either due to food unavailability or inaccessibility the latter being caused by financial shenanigans). Thus, there is a need to adopt sustainable and exhaustive approaches that could adequately serve on diverse agro-ecological zones of the country.

On the other hand, there are numerous factors that impede agricultural sector in the country. Adjustment to climate change impacts has been a major challenge among the smallholder farmers 10 . This is because they have weak adaptive capacity either to cope or recover from such a dreadful condition. Since more than $70 \%$ of the agricultural industry is dominated by the smallholder farmers, it is evident that the impact of climate change to them is worst compared to medium and large scale. This has ultimately elevated poverty levels in rural areas $[2,11]$. This observation is in agreement with the reports by UNDP [24, 25] which informs that most developing countries have elevated poverty levels mainly due to poor yields.

Market constraint is another challenge that has been affecting agriculture. This refers to uncontrolled market systems that involve goods and inputs related to agriculture. In terms of inputs, the flow of fertilizers and seeds to farmers has been inconvenient [26]. In most cases, these inputs have been reaching people out of their farming calendars. In so doing, the provided inputs become useless/fruitless. In this aspect of marketing, the distribution of food within the country has been less convenient. Among the causes for this inconvenience is poor infrastructure such as roads and storage facilities.

For example, in 2014 there were optimal yields gotten in the main producing regions (Iringa, Mbeya, Morogoro, Rukwa and Kigoma); however, shortage of storage facilities was the main cause for yield destruction. While the yields were destroyed in those regions, other parts of the country had food shortage.

As a survival strategy, some farmers intended to sell their produce to other countries, but were forbidden by the government as it could arise food shortage within the country. Ultimately, this situation brought about enormous loss to some farmers, who some of them decided not to further engage in agriculture in the next season. Thus, there is a need to streamline all market components so that it benefits the farmers and related stakeholders.

Inadequate technology is among the major obstacle for agricultural development in the country as it limits agricultural intensification. This encompasses low use of improved inputs such as seed, fertilizers and other farm implements. Harnessing irrigation potentials is significantly impacted by poor technology [2, 27, 29]. It is only less than $4 \%$ of the potential irrigable land that has been harnessed. This exploitation is quite different from that in the developed countries where over $50 \%$ of such potential is exploited. Sufficient budget could be of help in exploiting the irrigation potentials, especially by hiring innovative machines and considerable technology.

Sparingly, the government through TAFSIP aimed to comprehensively transform the sector to achieve food and nutrition security, and reduce poverty by allocating $10 \%$ of its budget in agriculture sector [28, 29]. However, this financial allocation has not been made. It is this financial discrepancy that impedes the implementations of various agricultural programs and projects. If this budget were allocated, among other things it could facilitate the provision of agricultural subsidies to farmers. So, as long as the allocation was not made, the farmers have continued to be economically powerless due to such insignificant services.

The solicitation of agricultural loans among the farmers has also been a challenge. The easiest way of acquiring such a loan is through banks. However, most of the farmers have no entitlement to loans access due to lack of relevant collaterals required by most financial institutions. Even for those who access, they are not sure if they could manage to pay back given the market constraints of their prospective yields.

Agricultural turbulence has also affected the national GDP throughout the time frame. For example, from the year 2000 to 2009, the agricultural contribution to GDP fell from 29 to $25 \%$, respectively. While that happened, the nutrition level fell from 25 to $23.5 \%$ within the same time frame. Specifically, the malnutrition is more pronounced to children under 5 years [30-33].

To reverse this trend, there is a need to employ the newest techniques in agricultural industry that can transform agriculture from subsistence to commercial [3033]. This is because numerous programs, initiatives and project have been established and implemented; however, increased incidences of food shortage and poverty have been reported. Since 1980 to date, a series of initiatives have been in place with either less fruits or shortterms impacts.

In this aspect, the over dependency on foreign support appeared to increase the unsustainability of the sector. In most cases, when the project phases out, the operation of all agricultural activities which were formerly done by the project is suspended. The surest solution to curb this uncertainty is to increase the generation of national income and allocate more funds in agricultural sector.

Alternatively, the government through the Ministry of Agriculture should adhere to the demands of authentic and potential challenges through appropriate review of its policy to make it more vigorous and friendly to 
small holder farmers. As usual, flawless consideration of different agro-ecological zones in the reviews should be adhered. This will have long-term significant contributions to socioeconomic development of the people. Likewise, the provision of raw materials to domestic industries will be ensured from the local production.

\section{Conclusions}

This study has laid down some empirical conclusions that when adopted can be a good basis for agricultural intensification in the country. Among others, it revealed that despite the temporal increase in the total yields of the major food crops, the food demand has been widening due to sudden population increase and other allied factors. The observed increase in total yields has happened due to expansion of crop land. Besides, the study noticed that the yields per hectare in tons have been fluctuating at the decreasing trend. The enormous and ever-expanding food demand has necessitated usual policy responses to overcome the associated challenges. This has involved the implementation of various programs and projects that could upsurge crop yields. On the same basis, the NAP 2013 has been identifying some arising issues that impede agricultural production. Among others, the impacts of climate change and soil degradations have been adequately identified.

Given to this vulnerability, the impetus, tireless and improved instruments (including more robust policies) should be employed in agriculture sectors. Determination should be well set to overcome the huddles. To curb these challenges, this study proposes the adoption of drought-resistant crops and increased fertilizations have been proposed. However, the technology and knowledge of curbing the same have not well tricked down at local scale. The assessment on the utilization of various research findings can be the further research priorities.

\section{Abbreviations}

FAO: Food and Agriculture Organization; GDP: Gross Domestic Product; IPCC: Intergovernmental Panel on Climate Change; MALF: Ministry of Agriculture, Livestock and Fishery; NAP: National Agricultural Policy; URT: United Republic of Tanzania; WRB: World Reference Base of Soil Resource.

\section{Authors' contributions}

Both authors (MYM and XH) designed the study, while MYM carried out the majority data collection portion. $\mathrm{XH}$ cooperated in the research, providing input throughout and reviewing details. Both authors wrote, reviewed and commented on the manuscript. Both authors read and approved the final manuscript.

\section{Author details}

${ }^{1}$ Department of Geography and Environmental Studies, Solomon Mahlangu College of Sciences and Education, Sokoine University of Agriculture, Morogoro 3038, Tanzania. ${ }^{2}$ Centre of Excellence for Soil Biology, College of Resources and Environment, Southwest University, Chongqing 400715, China. ${ }^{3}$ School of Plant Biology, University of Western Australia, Crawley 6009, Australia.

\section{Acknowledgements}

We give thanks to the College of Resources and Environment of Southwest University for supporting this study. We also wish to thank research assistants who involved in the data collection process.

\section{Competing interests}

The authors declare that they have no competing interests.

\section{Availability of data and materials \\ Not applicable.}

\section{Consent for publication}

Not applicable.

Ethics approval and consent to participate

Not applicable.

\section{Funding}

This study was funded by the College of Resources and Environment of Southwest University of China.

\section{Publisher's Note}

Springer Nature remains neutral with regard to jurisdictional claims in published maps and institutional affiliations.

Received: 8 March 2018 Accepted: 16 October 2018

Published online: 22 October 2018

References

1. URT. National population policy. Dar es Salaam: Government Publishing Press; 2006

2. URT. Poverty and human development report "research and analysis working group. Dar es Salaam: Government Publishing Press; 2009.

3. URT. National agriculture policy. Dar es Salaam: Government Publishing Press; 2013.

4. Food and Agriculture Organization of the United Nations. Soil fertility management in support of food security in Sub-Saharan Africa. Rome: FAO; 2001.

5. FAO. FAOSTAT, Rome. Food and Agriculture Organization, Rome. 2012. http://faostat.fao.org/. Accessed 10 Jan 2017.

6. FAO: Declaration of the world summit on food security. World Summit on Food Security. Neufeldt H, Jahn M, Campbell BM. Beyond climate smart agriculture: toward safe operating spaces for global food systems. Agric Food Secur. 2013; 2:12.

7. Reddy AA. Food security indicators in India compared to similar countries. Curr Sci. 2016;111(4):632-40.

8. Lobell DB, Burke MB. On the use of statistical models to predict crop yield responses to climate change. Agric For Meteorol. 2010;150(11):1443-52.

9. Mkonda MY. Rainfall variability and its association to the trends of crop production in Mvomero District, Tanzania. Eur Sci J. 2014;10(20):263-73.

10. URT. United Republic of Tanzania, national adaptation programme of action (NAPA). Dar es Salaam: Division of Environment, Vice President's Office; 2007.

11. URT. Review of food and agricultural policies in the United Republic of Tanzania. MAFAP country report series. Rome: FAO; 2014.

12. Intergovernmental Panel on Climate Change. Climate change 2013: the physical science basis. In: Stocker TF, Qin D, Plattner GK, Tignor M, Allen SK, Boschung J, Nauels A, Xia Y, Bex V, Midgley PM, editors. Contribution of working group I to the fifth assessment report of the intergovernmental panel on climate change. Cambridge: Cambridge University Press; 2013.

13. Intergovernmental Panel on Climate Change. In: Field CB, Barros VR, Estrada YO, Genova RC, Girma B, Kissel ES, Levy AN, MacCracken S, Mastrandrea PR, White LL, editors. Climate change 2014 impacts, adaptation, and vulnerability. Part A: global and sectoral aspects. Contribution of working group II to the fifth assessment report of the intergovernmental panel on climate change. Cambridge: Cambridge University Press; 2014. 
14. Food and Agriculture Organization. FAO/Unesco soil map of the World, revised legend, with corrections and updates. (World Soil Resources Report 60) FAO, Rome (reprinted with updates as Technical Paper 20, ISRIC, Wageningen, 1988.

15. Food and Agriculture Organization: FAOSTAT Agriculture Data. FAO, Rome, Italy. 2003. http://apps.fao/cgi-binnph-db.pl?suset=agriculture.

16. Kangalawe RYM. Climate change impacts on water resource management and community livelihoods in the southern highlands of Tanzania. Climate Dev. 2016. https://doi.org/10.1080/17565529.2016.1139487.

17. Rowhani P, Lobell DB, Linderman M, Ramankutty N. Climate variability and crop production in Tanzania. Agric For Meteorol. 2011;15:449-60.

18. Neufeldt H, Jahn M, Campbell B. Beyond climate smart agriculture: toward safe operating spaces for global food systems. Agric Food Secur. 2013;2(12):16-8.

19. Paavola J. Livelihoods, vulnerability and adaptation to climate change in Morogoro, Tanzania. Environ Sci Policy. 2008;11:642-54.

20. Wik M, Pingali P, Broca S. Global agricultural performance: past trends and future prospects. Washington DC: World Bank; 2008.

21. Sen AK. Development as freedom. In: Knopf A, editor. Agricultural Development. Oxford: Oxford University; 1999.

22. Harvey CA, Chacón M, Donatti Cl. Climate-smart landscapes: opportunities and challenges for integrating adaptation and mitigation in tropical agriculture. Conserv Lett. 2014;7:77-90.

23. Conceição P, Levine S, Lipton M, Warren-Rodríguez A. Toward a food secure future: ensuring food security for sustainable human development in Sub-Saharan Africa. Food Policy. 2016;60:1-9.

24. UNDP. World population prospects: the 2000 revision. New York: Department of Economic and Social Affairs; 2000.
25. UNDP. Africa human development report 2012: towards a food secure future. New York: United Nations Development Programme (UNDP); 2012.

26. Cornia G, Deotti L, Sassi M. Sources of food price volatility and child malnutrition in Niger and Malawi. Food Policy. 2016;60:20-30.

27. ECA (Economic Commission for Africa). Harnessing technologies for sustainable development. Addis Ababa: ECA; 2002.

28. URT. Tanzania agriculture and food security investment plan (TAFSIP). Dar es Salaam: Government Publishing Press; 2011.

29. URT. Participatory agricultural development and empowerment project (PADEP). Dar es Salaam: Government Publishing Press; 2003.

30. Mkonda MY, He XH. Climate variability, crop yields and ecosystems synergies in Tanzania's semi-arid agro-ecological zone. Ecosyst Health Sustain. 2018;1:1. https://doi.org/10.1080/20964129.2018.1459868.

31. Mkonda MY, He XH, Festin ES. Comparing smallholder farmers' perception of climate change with meteorological data: experiences from seven agro-ecological zones of Tanzania. Weather Clim Soc. 2018. https://doi. org/10.1175/wcas-d-17-0036.1.

32. Mkonda MY, He XH. Yields of the major food crops: implications to food security and policy in Tanzania's semi-arid agro-ecological zone. Sustainability. 2017;9(8):1490. https://doi.org/10.3390/su9081490.

33. Mkonda $\mathrm{MY}$, He XH. Are rainfall and temperature really changing? Farmer's perceptions, meteorological data, and policy implications in the Tanzanian semi-arid zone. Sustainability. 2017;1:1. https://doi. org/10.3390/su9081412.
Ready to submit your research? Choose BMC and benefit from:

- fast, convenient online submission

- thorough peer review by experienced researchers in your field

- rapid publication on acceptance

- support for research data, including large and complex data types

- gold Open Access which fosters wider collaboration and increased citations

- maximum visibility for your research: over 100M website views per year

At BMC, research is always in progress.

Learn more biomedcentral.com/submissions 